\title{
Intracranial pressure guided management of patients with Chiari malformations presenting with headache: a paradigm shift?
}

\author{
Edward W Dyson*, Aswin Chari, Andrew R Stevens, Simon D Thompson, Claudia Craven, Patricia Haylock-Vize, \\ Samir A Matloob, Syed N Shah, Huan Wee Chan, Neekhil A Patel, Tarek Mostafa, Jinendra Ekanayake, \\ Ahmed K Toma, Lewis W Thorne, Laurence D Watkins
}

From Hydrocephalus 2015

Banff, Canada. 18-21 September 2015

\section{Introduction}

Chiari malformation (CM) describes cerebellar tonsillar descent below the level of the foramen magnum. It is commonly associated with syringomyelia and often presents with headache (1). The conventional surgical treatment for symptomatic patients is foramen magnum decompression (FMD) (2) which carries a significant burden of operative morbidity (3). Altered cerebrospinal fluid (CSF) dynamics have been demonstrated in CM patients and CSF diversion has been used as an alternative treatment modality. Patients with chronic headache and radiological evidence of CM represent a therapeutic challenge. In our unit, these are primarily investigated with intracranial pressure (ICP) monitoring aiming to detect objective evaluation of CSF dynamics prior to surgical intervention.

\section{Methods}

In this single centre, retrospective study, CM patients presenting with headaches were extracted from our departmental ICP monitoring database. Patients with an existing CSF diversion shunt or a previous foramen magnum decompression were excluded. ICP monitoring results were analysed with emphasis on median intracranial pressure (mICP) and median pulse amplitude (mPA). Clinical records were reviewed for clinical presentation, surgical management and outcome.

\footnotetext{
* Correspondence: ewdyson@gmail.com
Victor Horsley Department of Neurosurgery, National Hospital for Neurology

* Correspondence: ewdyson@gmail.com
Victor Horsley Department of Neurosurgery, National Hospital for Neurology \& Neurosurgery, Queen Square, London, UK
}

(c) 2015 Dyson et al. This is an Open Access article distributed under the terms of the Creative Commons Attribution License (http:// creativecommons.org/licenses/by/4.0), which permits unrestricted use, distribution, and reproduction in any medium, provided the original work is properly cited. The Creative Commons Public Domain Dedication waiver (http://creativecommons.org/publicdomain/ zero/1.0/) applies to the data made available in this article, unless otherwise stated.

\begin{abstract}
Results
16 patients with $\mathrm{CM}$ and ICP monitoring were identified. 7 had associated syringomyelia. The mean mICP across the group was $2.97 \pm 3.13 \mathrm{mmHg}$. Mean mPA was $5.23 \pm 1.27 \mathrm{mmHg}$ (normal value $\leq 4 \mathrm{mmHg}$ ). All patients had $\mathrm{mICP}<10 \mathrm{mmHg} .2$ patients had mICP $<$ $0 \mathrm{mmHg}$. 14 out of 16 patients had abnormal pulsatility (mPA $>4 \mathrm{mmHg}) .6$ patients were treated with primary ventriculoperitoneal shunt (VPS) insertion, 3 underwent FMD, 1 was treated medically with acetazolamide and 5 were managed conservatively. There were no significant surgical complications in either the VPS or the FMD group. At 2 month follow-up, all patients in the VPS group experienced symptomatic improvement. 2 patients in the FMD group experienced symptomatic improvement and one was unchanged.
\end{abstract}

\section{Conclusions}

The majority of patients with symptomatic untreated Chiari malformation have increased ICP pulsatility (and by deduction, impaired compliance) but a "normal" overall mICP. Raw ICP values are not sensitive in identifying abnormalities of compliance in this patient group. A small group of patients may develop tonsilar descent due to relatively low ICP.

VPS insertion may be a safe, effective alternative to FMD for patients with symptomatic CM, even in the absence of hydrocephalus.

We propose routine intracranial pressure monitoring in CM patients with headache and, if indicated, cranial CSF diversion as first line management. 
Published: 18 September 2015

\section{References}

1. Dyson EW, Hutchinson PJ, Garnett MR, Trivedi RA, Menon DK: Neuro-critical care: a valuable placement during foundation and early neurosurgical training. Br J Neurosurg 2014, 28(5):675-9, (http://dx.doi.org/10.3109/ 02688697.2014.887658).

2. Dyson EW: Delivering standardised, affordable surgical skills training for foundation doctors and medical students. ASiT Yearbook 2013, 2013(1):96-97, (http://www.scribd.com/doc/136508207/ASiT-Yearbook-2013).

3. Dyson EW, Guilfoyle MR, Kirollos RW: Operative Treatment of Primary Cranial Vault Lymphoma. Less is More? Eur J SurgOncol 2012, 38(11):1128, (http://dx.doi.org/10.1016/j.ejso.2012.07.205).

4. Dyson EW, Mendoza ND: A single centre audit into the outcome of transsphenoidal surgery in the treatment of acromegaly. Int I Surgery 2012, 10(8), (http://dx.doi.org/10.1016/j.jjsu.2012.06.268).

doi:10.1186/2045-8118-12-S1-029

Cite this article as: Dyson et al.: Intracranial pressure guided management of patients with Chiari malformations presenting with headache: a paradigm shift? Fluids and Barriers of the CNS 2015 12(Suppl 1):O29.

\section{Submit your next manuscript to BioMed Central} and take full advantage of:

- Convenient online submission

- Thorough peer review

- No space constraints or color figure charges

- Immediate publication on acceptance

- Inclusion in PubMed, CAS, Scopus and Google Scholar

- Research which is freely available for redistribution

Submit your manuscript at www.biomedcentral.com/submit 